\title{
Arakawa's Reaction of Fractions of Milk Fed at One Feeding.
}

\author{
84th Report of the Peroxidase Reaction.
}

By

\section{Mitsuru Hasegawa.}

(長谷川 盈)

(From the Pediatric Department, Faculty of Medicine, Tohoku

Imperial University, Sendai. Director: Prof. A. Sato.)

The diurnal change of human milk as to its Arakawa's reaction was studied by T. Yoshida and M. Yoshida ${ }^{1)}$ in 1932. Arakawa's reaction of one and the same lactating mother was observed by $\mathrm{Ug} \mathrm{a}^{2}$ for as long as almost one year. In the present paper I desire to report the reaction of fractions of milk sucked at one feeding.

\section{Method of Experiment.}

1. Materials. All the lactating women were mothers of patients at private expense; so much the more difficult was the task.

2. Obtaining of milk fractions, each mother bagan to feed her baby on command, and stopped feeding at the end of every one minute. As soon as feeding was stopped, 2 c.c. of milk was obtained, and feeding was resumed again. Such was repeated five times, and six milk fractions in all were collected, because one was obtained just before the feeding.

\section{Result of Experiment.}

1. Constancy of the reaction in different milk portions.

The fact that Arakawa's reaction is a fairly constant one will be seen if the result in Case 11 and Case 13, for instance, is shown (Cf. Table 1).

1) T. Yoshida and M. Yoshida, Jika Zasshi, 1932, No. 380, 49.

2) Y. Ug a, Tohoku J. Exp. Med., 1935, 25, 564. 


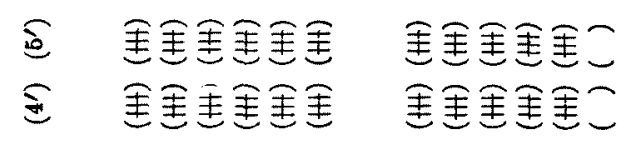

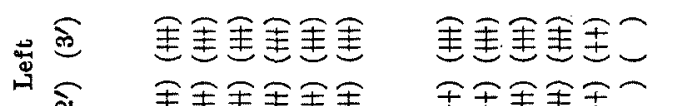

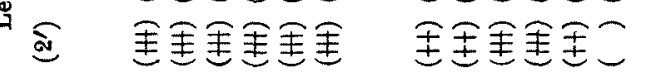

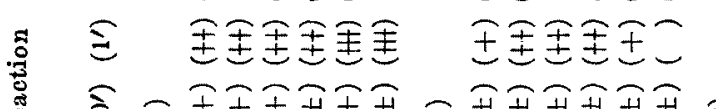

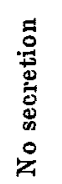

的王王开开开开开开开开茾

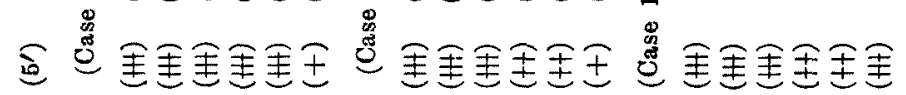

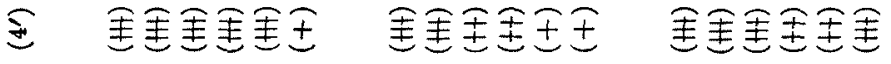

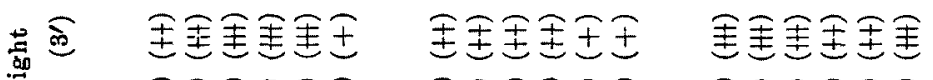

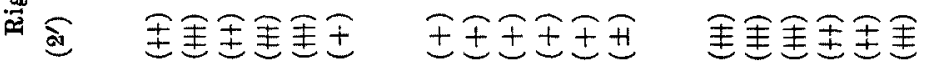

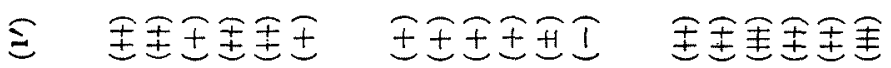

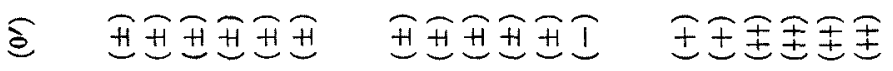

思
它金金金王金こ

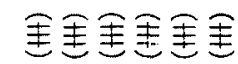

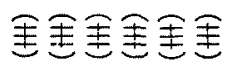
过王全金金金
金金金金毛毛
重严金金金金

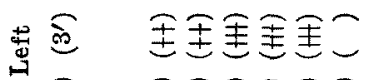

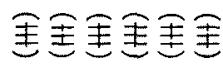
金金金金金金
可王王王王
金金金金金金
金金金金金金

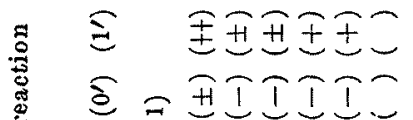

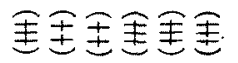
金金金金金金

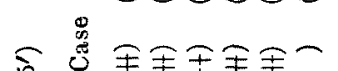
可王王开全王王

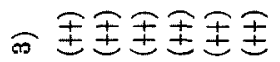
它它金金王金金气
递金王王王王王
菢
氞重金金金
美王王王王王

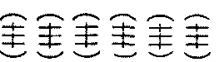
茄嵒重重重重重金
王王王王王王
重金金金金重
金金金金金重
王王王王开
金金金金金要
可琵全全全こ
开开开开开工
王金王全金主
可开开开开开
IIIIII
王王王王王王 

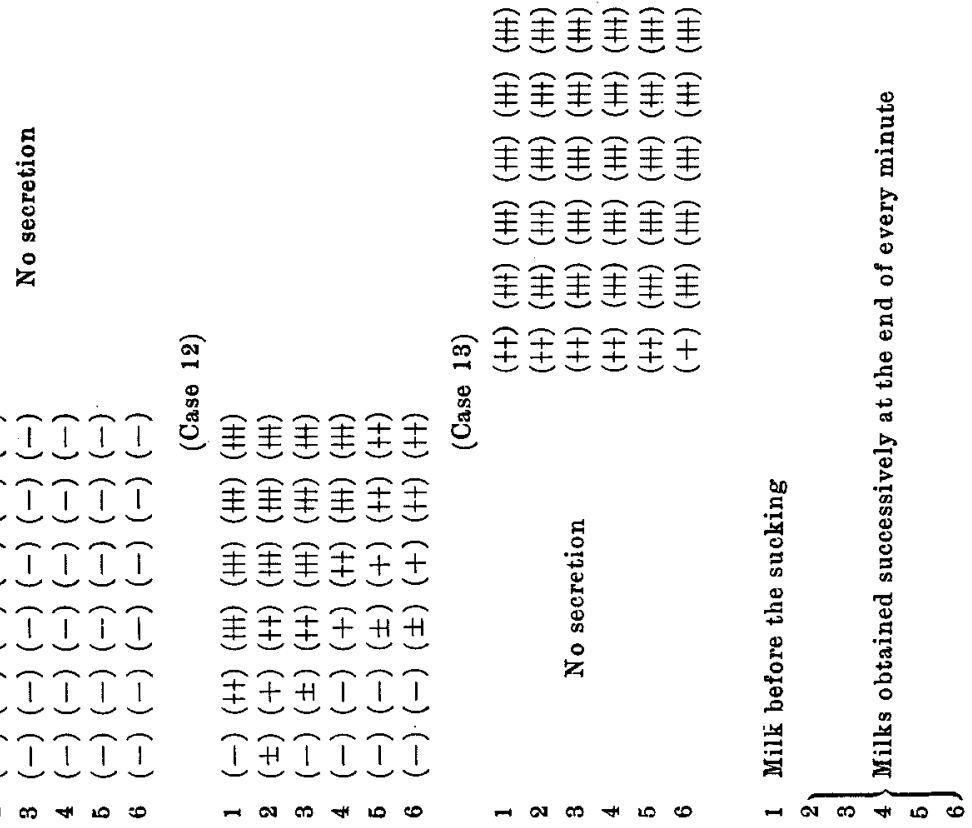

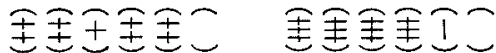

开干开茾

王王金主主こ

声声声㐊

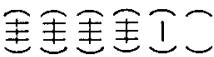
开开王开 导开声声

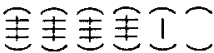
王草士口 琶琶て 开开妍开二 王王开厂 II开贲 กิฺฺ 㐊琶主 声声主毛

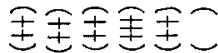
กิTTก 㻤 HT

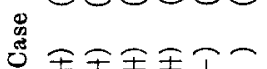
王声士心 三三三比

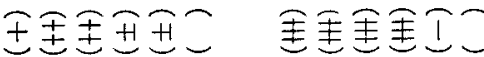
王弁开开一全金王厂 F干干形

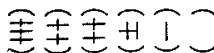
I표드

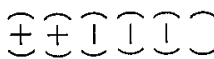
IIIII 开声开 - IIIIT工 尊 无干IIIE 胥

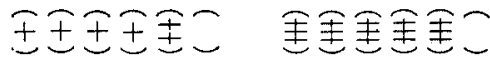
王开开王无 主金主金

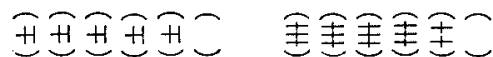
III I กT? T?

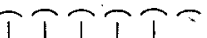

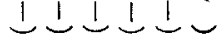
㐊士声声。 IIIII 开苛开 


\section{Table 2.}

Arakawa's reaction

$\left(0^{\prime}\right)\left(1^{\prime}\right)\left(2^{\prime}\right)\left(3^{\prime}\right)\left(4^{\prime}\right)\left(5^{\prime}\right)\left(0^{\prime}\right)\left(1^{\prime}\right)\left(2^{\prime}\right)\left(3^{\prime}\right)\left(4^{\prime}\right)\left(5^{\prime}\right)$

Case 11 (real result)

Mere supposition

$1(-)(-)(-)(-)(-)(-)(-)(-)(-)(-)(-)(-)$

$2(-)(-)(-)(-)(-)(-)(+)(H)(H)(H)(H+)(H)$

$3(-)(-)(-)(-)(-)(-)(-)(-)(-)(-)(-)(-)$

$4(-)(-)(-)(-)(-)(-)(+)(+)(t+)(H)(H t)(H t)$

$5(-)(-)(-)(-)(-)(-)(-)(-)(-)(-)(-)(-)$

$6(-)(-)(-)(-)(-)(-)(+)(++)($ H) $($ H $)($ H) $($ HW $)$

Case 13 (real result)

Mere supposition

$1(t+)(H)(H t)(H)(H t)(H t) \quad(t t)(H t)(H)(H)(H)(H)$

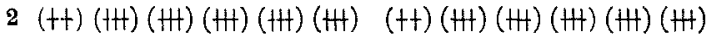

$3(t t)(H H)(H t)(H H)(H H)(H t)(-)(-i(-)(-)(-)(-)$

$4(+t)(H+)(H+)(H)(H)(H) \quad(+t)(H+)(H)(H+)(H t)(H)$

$5(\mathrm{Ht})(\mathrm{Ht})(\mathrm{HH})(\mathrm{HH})(\mathrm{H})(\mathrm{HH})(\mathrm{tt})(\mathrm{Ht})(\mathrm{HH})(\mathrm{HH})(\mathrm{HH})(\mathrm{HH})$

$6(+)(H)(H)(H+)(H)(H)(-)(-)(-)(-)(-)(-)$
The real result in Case 11 and Case 13 will show that Arakawa's reaction is fairly constant in five or six milk portions, so that such a result as is shown under the result of mere supposition (Cf.Table 2) will never occur. If the sixth portion in Case 11 had been examined, then the result would have been most probably (-) $0^{\prime}$ $(-) 1^{\prime}(-) 2^{\prime}(-) 3^{\prime}$

$(-) 4^{\prime}(-) 5^{\prime}$ and could never have been $(+) 0^{\prime}(+t) 1^{\prime}(H+) 2^{\prime}(H+) 4^{\prime}$ (H) $5^{\prime}$ for instance.

Thus Arakawa's reaction of one portion taken during feeding (or before it) may be taken as exactly or approximately representing the reaction of another portion or that of the most portion of one feeding. Therefore milk obtained before feeding is not only appropriate for the examination of Arakawa's reaction in most cases, but also quite practical, though this point will be discussed again later. The tolerable constancy of Arakawa's reaction in different milk portions will further be seen from the results in Cases $1,2,3,4,6,7$ and 10 (Cf. Table 3). The tolerable constancy of the reaction in different portions will be seen from these results in Table 3 (Cf. Table 3). Here is, however, a question about the result of the last portion. In these cases shown in Table 3 , the last portion-at least the last portion obtained-showed almost the same intensity of reaction as the first. Bearing on this point we shall glance over some other cases in the next paragraph.

2. Intensity of the reaction in the last portion. If we take into consideration Case 5 (both breasts), Case 8 (right breast), Case 9 (right breast), Case 12 (right breast), then we see that the last portion is becoming weakened in reaction (Cf. Table 4 ).

This result, shown in Table 4, is in coincidence with that of our 


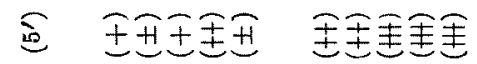

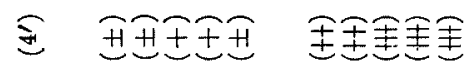

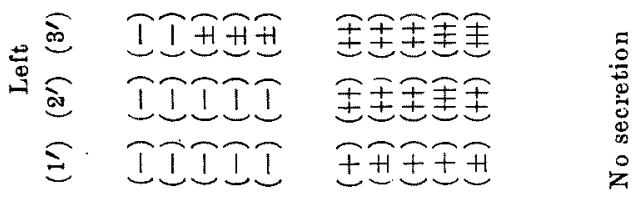

อ。IIIII

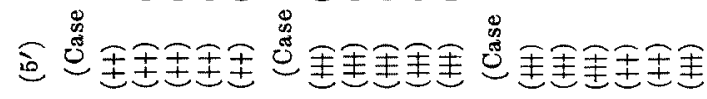

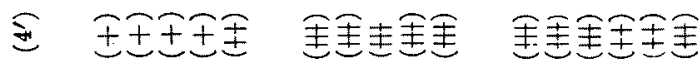

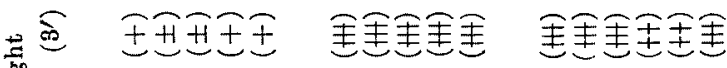

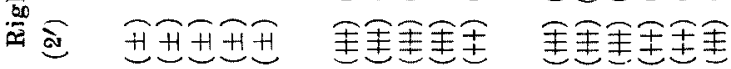

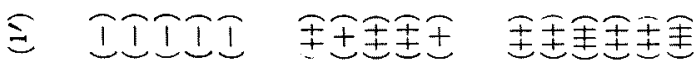

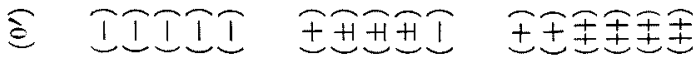

$\dot{0}$

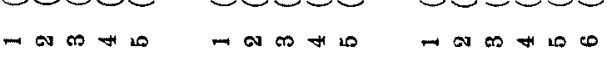

舅

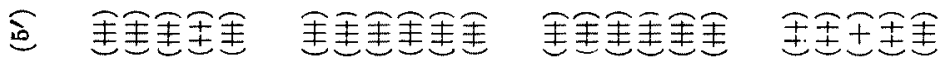

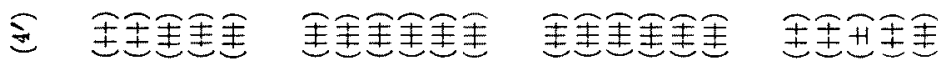

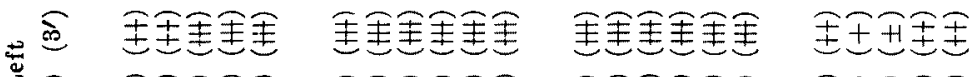

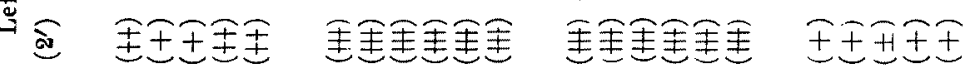

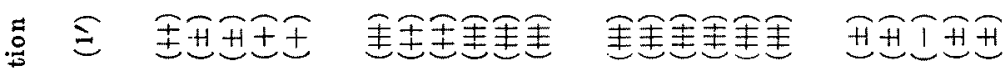

的开IIII

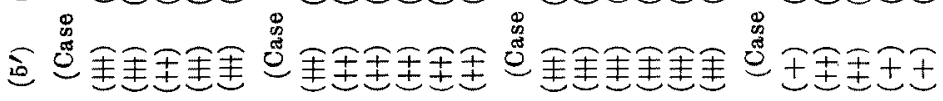

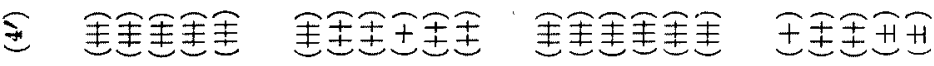

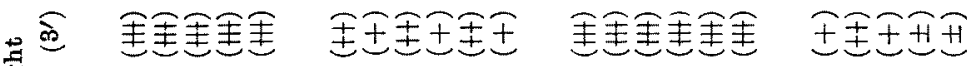

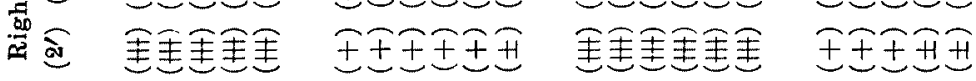

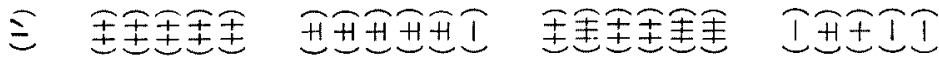

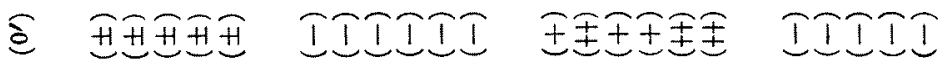

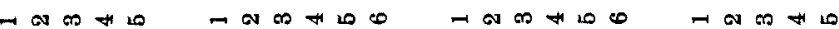




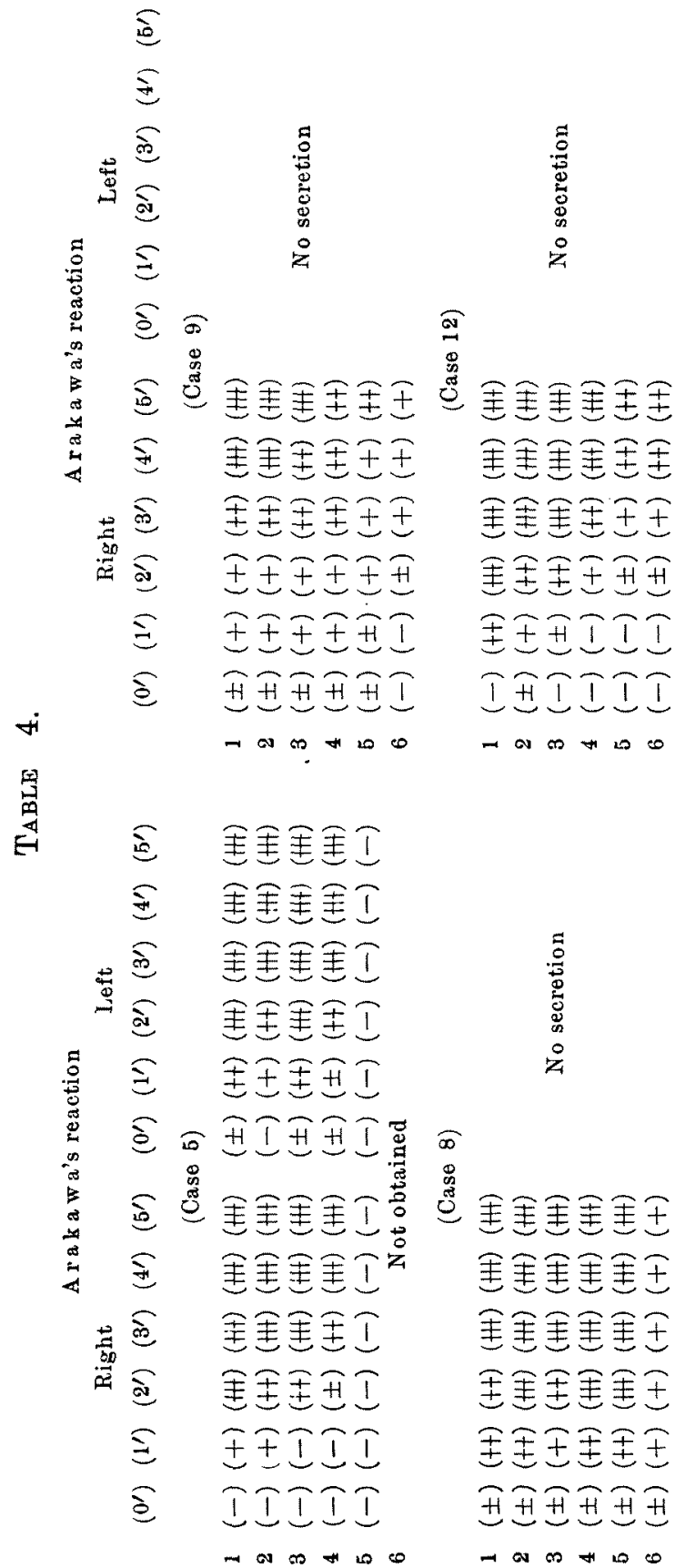

daily experience, because we have gathered from our daily practice that we can take the reaction of a milk sample obtained before sucking as such, while, of a sample obtained after sucking, some reservation should be made. In this regard Case 9 is of special interest, because the result of the reaction in this case may be considered as another extreme example of that propensity which the other cases given in Table 4 have shown. And it will not be without reason to suppose that if more fractions of milk had been obtained in the cases shown in Table 2, the very last fraction might have been weaker in reaction.

3. Simplified result of Arakawa's reaction 
of different milk fractions. If we simplify different results shown in the preceding paragraph, we shall be able to classify the course of the milk reaction during one feeding into two or three different forms, which may be diagrammatically shown in the accompanying figure (Cf. Figure). Though the cases investigated were only few in number, the reverse form of Type II or Type B may probably never occur. So the practical conclusion will be; the first frac-

Figure.

The Constant Type

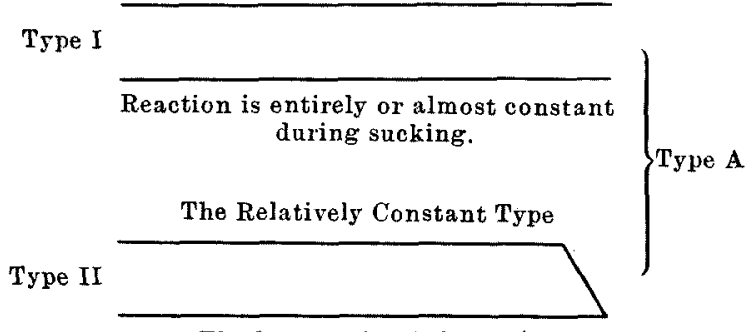

The last portion is becoming weaker in reaction.

The Degenerating Type

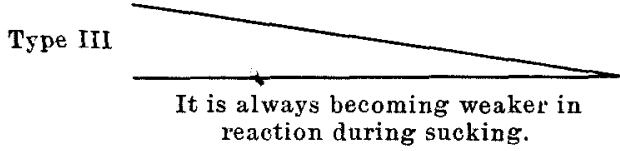
Type B tion of milk or a portion taken during the feeding will be seen as representing in respect to Arakawa's reaction the whole portion of milk to be fed at that time.

A Word concerning Difficulty of the Attempt.

The attempt reported in the present paper is not so easy a task as it may appear. The ideal condition for the attempt is to train mothers and make them accustomed to it. Only then should the task be begun; especially because the mental state of mothers seems to be a factor of some influence. ${ }^{3)}$ But such was an utter impossibility under the conditions under which this work was undertaken. Thus, it is not to be excluded that the result of reaction in each case might have been more constant.

\section{Summary.}

This work was undertaken to test Arakawa's reaction of dif-

3) A.Sato and Y. Moriwaki, Tohoku J. Exp. Med,, 1936, 29, 384. 
ferent portions of human milk fed at one time. Milk was obtained in each case just before feeding and then at the interval of each minute during the one feeding. It was very difficult to collect a larger number of such cases, because many an infant, who got very angry and wanted to drink no more milk, made it impossible to continue the work in that special case. But I was able to investigate the reaction as long as about 5 or 6 minutes in 13 cases.

And the result was that the reaction of different milk portions was tolerably constant, so that the fraction obtained before feeding as well as during feeding would, as regards Arakawa's reaction, be considered as representing the whole milk fed at the time (Cf. Figure).

\section{Conclusion.}

A rakawa's reaction of the fraction obtained before feeding may be considered as representing the reaction of the whole milk fed at the time. 